\title{
Konstitusionalitas Shahifah Madinah
}

\author{
Ahmad Sadzali \\ Dosen Fakultas Hukum Universitas Islam Indonesia \\ Email: sadzali@uii.ac.id
}

\begin{abstract}
Abstrak
Sebagai agama yang rahmatan lil 'alamin dan shalih li kulli zaman wa makan, sudah semestinyaajaran-ajaran Islam tetapeksispadasetiapaspekkehidupan. Tidakterkecuali pada aspek hukum tata negara. Shahifah Madinah adalah bukti sejarah yang sangat otentik bahwa Islam tidak absen dalam aspek tata negara. Shahifah Madinah menjadi dasar hukum dalam hubungan dan interaksi sosial di tengah penduduk Madinah di masa Rasulullah SAW. Penelitian ini bertujuan untuk menjawab pertanyaan apakah Shahifah Madinah layak untuk disebut sebagai sebuah konstitusi ataukah tidak. Penelitian ini merupakan penelitian normatif dengan pendekatan analisis teoritis ini mencoba menilai Shafihaf Madinah dari perspektif teori-teori konstitusi modern dengan sumber data dari dokumen sejarah dan hukum tata negara. Hasil penelitian ini menunjukkan bahwa pada dasarnya Shahifah Madinah dapat disebut sebagai sebuah konstitusi dalam bentuknya yang sederhana dan sesuai dengan kebutuhan pada konteks ketika itu. Substansi konstitusionalisme sudah terkandung sangat jelas di dalam Shahifah Madinah. Meskipun memang harus diakui, jika dibandingkan dengan konstitusi modern, Shahifah Madinah masih belum lengkap.
\end{abstract}

Kata Kunci: Konstitusionalitas, Shahifah Madinah, Kontekstualisasi, Hukum Tata Negara Islam 


\title{
Constitutionality Of The Charter Of Medina
}

\author{
Ahmad Sadzali \\ A Lecturer of Faculty of Law Universitas Islam Indonesia
}

\begin{abstract}
As a religion which is rahmatan lil 'alamin and shalih li kulli zaman wamakan, it is appropriate that Islamic teachings exist in every aspect of human life, including in the aspect of constitutional law. The Charter of Medina is an authentic proof that Islam was present in the constitutional law. The Charter of Medina served as the legal basis in social interaction and relationship among the community in Medina during the era of the Prophet Muhammad. This study aimed to answer the question whether it is appropriate to consider the Charter of Medina as a constitution. This was a normative study using theoretical analysis, which analyzed the Charter of Medina from the perspective of modern constitutional theories. The data sources were from historical and constitutional law documents. The results showed that basically the Charter of Medina could be considered as constitution in its simple form which met the need of the era. This charter clearly contained the substances of constitution. However, it has to be admitted that, compared to modern constitution, the Charter of Medina is still incomplete.
\end{abstract}

\section{Keywords: Constitutionality, Charter of Medina, Contextualization, Islamic Constitutional Law}

\section{PENDAHULUAN}

Konsep Islam sebagai agama yang rahmatan lil 'alamin seringkali menjadi tema diskursus yang tiada henti. Universalitas agama Islam kerap menjadi perbincangan di berbagai meja diskusi dan forum-forum lainnya, mengingat agama yang diturunkan Allah lebih dari empat belas abad yang lalu ini harus membuktikan eksistensinya dalam menghadapi perkembangan zaman. Seperti yang kita ketahui, wahyu telah berhenti seiring dengan wafatnya Nabi Muhammad SAW, sedangkan zaman dan kehidupan umat manusia terus berkembang. 
"Tantangan" untuk membuktikan eksistensi Islam termasuk ajaran-ajarannya di tengah perkembangan zaman modern saat ini datang dari setiap aspek kehidupan. Tidak terkecuali pada aspek kenegaraan atau tata negara. Sebagai agama dan ajaran yang universal (shalih li kulli zaman wa makan), menjadi pekerjaan besar bagi umat Islam untuk melakukan kontekstualisasi ajaran Islam pada aspek tata negara. Umat Islam harus mampu menunjukkan bahwa ajarannya dapat diterapkan dalam masalah kenegaraan dan tata negara, baik di masa sekarang maupun di masa yang akan datang.

Terlepas dari polemik hubungan agama dan negara, yang jelas sejarah telah membuktikan bahwa Islam merupakan agama yang kamil yang telah memuat dasar-dasar norma dalam menjalankan kehidupan, termasuk pada aspek tata negara atau kenegaraan. Bahkan dalam skala yang sangat luas bukan saja dalam skala negara - Islam merupakan agama yang memiliki "konstitusi" untuk kehidupan di dunia dan di akhirat. Dengan konstitusi itulah kemudian umatnya menjalani kehidupan mereka.

Dalam tataran praktis kenegaraan, Islam juga tidak luput memberikan contoh keteladanan yang dapat diikuti. Shahifah Madinah adalah bukti sejarah yang sangat otentik atas hal tersebut. Shahifah Madinah menjadi dasar hukum dalam hubungan dan interaksi sosial di tengah penduduk Madinah di masa Rasulullah SAW. Melalui Shahifah ini, Rasulullah SAW memberikan pelajaran yang sangat berharga bagaimana membangun sebuah komunitas besar berskala negara, yang terdiri dari masyarakat heterogen.

Dalam konteks negara modern, Shahifah Madinah menjadi menarik untuk dijadikan objek kajian tata negara. Penelitian ini mencoba untuk mendudukan Shahifah Madinah pada pusaran teori-teori konstitusi dalam hukum tata negara modern. Tujuannya untuk menjawab apakah Shahifah Madinah layak disebut sebagai sebuah konstitusi ataukah tidak. Dan salah satu manfaatnya adalah kontekstualisasi Shahifah Madinah dalam hukum tata negara moden, sebagai bukti konkrit dan otentik dalam mengelola sebuah negara yang memiliki latar belakang masyarakat yang majemuk, termasuk adanya perbedaan agama atau keyakinan. Sebab dewasa ini, perbedaan keyakinan seringkali menjadi masalah serius yang dipersoalkan dalam kehidupan berbangsa dan bernegara. Bahkan tak jarang masalah ini menjadi 
sebab timbulnya konflik yang suatu saat bisa saja mengancam kelangsungan Negara Kesatuan Republik Indonesia.

\section{TEORI KONSTITUSI MODERN}

Paham konstitusionalisme lahir pada abad XIX sebagai lanjutan dari paham negara berdasarkan hukum. Paham konstitusionalisme ini juga lahir sebagai salah satu mekanisme untuk membatasi kekuasaan. ${ }^{1}$ Artinya, kajian tentang teori-teori konstitusi ataupun paham konstitusionalisme tidak dapat dipisahkan dari kajian tentang konsep negara hukum². Karena pada dasarnya, konstitusi sendiri merupakan perwujudan konkrit dari sebuah negara hukum. ${ }^{3}$

Secara etimologis, konstitusi dapat diartikan sebagai segala ketentuan dan aturan mengenai ketatanegaraan, atau Undang-Undang Dasar suatu negara. ${ }^{4}$ Dengan demikian, konstitusi merupakan aturan dasar atau hukum dasar yang mengatur tentang ketatanegaraan di dalam suatu negara. Jadi, segala tindak-tanduk penguasa maupun warga negara harus tunduk pada konstitusi yang berlaku di negara tersebut.

1 Mahmuzar, Sistem Pemerintahan Indonesia: Menurut Uud 1945 Sebelum Dan Sesudah Amandemen (Ujungberung, Bandung: Nusa Media, 2010), hlm. 27; Lihat juga: Yusdani Yusdani, “Indonesia, Islam and Multicultural Citizenship," Millah: Jurnal Studi Agama 18, no. 1 (31 Desember 2018): 1-14, https://doi. org/10.20885/millah.vol18.iss1.art1.

2 Evi Noviawati, "Landasan Konstitusional Pembentukan Peraturan Perundang-Undangan," Jurnal Ilmiah Galuh Justisi 6, no. 1 (19 Mei 2018): 53-63, https:/ / doi.org/10.25157/jigj.v6i1.1246.

3 Untuk melihat prinsip-prinsip negara hukum dapat dilihat beberapa ide. Immanuel Kant dan Friedrich Julius Stahl dari kalangan ahli hukum Eropa kontinental memberikan ciri rechstaat, yaitu: a) Adanya jaminan terhadap hak asasi manusia; b) Adanya pemisahan atau pembagian kekuasaan; c) Pemerintahan yang berdasarkan atas hukum, serta; d) Adanya Peradilan Administrasi. Sedangkan A.V. Dicey, berasal dari kalangan ahli hukum anglo saxon, memberikan ciri rule of law, yaitu: a) Adanya supremasi hukum; b) Kedudukan yang sama di depan hukum, baik bagi rakyat biasa maupun bagi pejabat (equality before of the law); c) Terjaminnya hak-hak manusia oleh undang-undang dan putusan pengadilan. Menurut Laurence M. Friedman, negara hukum lebih identik dengan rule of law. Sedangkan rechstaat mengandung arti pembatasan kekuasaan negara oleh hukum. Namun dalam perkembangannya, gagasan Immanuel Kant, Julius Stahl, A.V. Dicey dan Laurence M. Friedman tersebut dirasakan belum memadai karena terjadi perkembangan demokrasi dan hukum dalam kehidupan bernegara. Kemudian pada tahun 1965 International Commission of Jurists dalam konferensinya di Bangkok merumuskan ciriciri pemerintahan demokratis di bawah rule of law sebagai berikut: a) Perlindungan konstitusional; b) Badan kehakiman yang bebas, tidak memihak; c) Pemilihan umum yang bebas; d) Kebebasan menyatakan pendapat; e) Kebebasan berserikat dan menyatakan pendapat, baik secara lisan maupun tulisan; f) Pendidikan bagi warga negara.

4 Departemen Pendidikan dan Kebudayaan Republik Indonesia, “KBBI Daring," diakses 15 September 2019, https:/ / kbbi.kemdikbud.go.id/entri/konstitusi. 
James Bryce mendefiniskan konstitusi sebagai "suatu kerangka masyarakat politik (negara) yang dioganisir dengan dan melalui hukum. ${ }^{5}$ C.F. Strong lebih dalam dan lebar lagi menjelaskan definisi konstitusi. Strong menyatakan:

“Konstitusi dapat pula dikatakan sebagai kumpulan prinsip-prinsip yang mengatur kekuasaan pemerintah, hak-hak pihak yang diperintah (rakyat), dan hubungan di antara keduanya. Konstitusi bisa berupa sebuah catatan tertulis; konstitusi dapat ditemukan dalam bentuk dokumen yang bisa diubah atau diamandemen menurut kebutuhan dan perkembangan zaman; atau konstitusi dapat juga berwujud sekumpulan hukum terpisah dan memiliki otoritas khusus sebagai hukum konstitusi. Atau, bisa pula dasar-dasar konstitusi tersebut ditetapkan dalam satu atau dua undang-undang dasar sedangkan selebihnya bergantung pada otoritas kekuatan adat-istiadat atau kebiasaan."

K.C. Wheare berpendapat bahwa sebuah konstitusi paling tidak biasanya digunakan untuk menggambarkan keseluruhan sistem ketatanegaraan dari suatu negara berupa kumpulan peraturan-peraturan yang membentuk, mengatur atau memerintah dalam pemerintahan suatu negara. Sebagian dari peraturan-peraturan tersebut ada yang bersifat legal, dalam arti pengadilan hukum mengakui dan menerapkan peraturan-peraturan itu, dan sebagian lainnya ada yang bersifat non-legal atau ekstra legal, yang berupa kebiasaan, persetujuan, adat atau konvensi, sesuatu yang tidak diakui oleh pengadilan sebagai hukum tetapi tidak kalah efektifnya dalam mengatur pemerintahan dibandingkan dengan apa yang secara baku disebut dengan hukum. ${ }^{6}$

Lebih lanjut K.C. Wheare menjelaskan, jika asal usul dari sebuah konstitusi dikaji lebih jauh, maka akan kita temukan bahwa konstitusi-konstitusi itu secara praktis tanpa kecuali, disusun dan diadopsi karena rakyat ingin

5 C. F. Strong, Konstitusi-Konstitusi Politik Modern: Studi Perbandingan Tentang Sejarah Dan Bentuk (Bandung: Penerbit Nusa Media, 2014), hlm. 14.

6 K. C. Wheare, Konstitusi-Konstitusi Modern, trans. oleh Muahmmad Hardani (Surabaya: Pustaka Eureka, 2003), hlm. 1. 
membuat permulaan yang baru, sejauh berkaitan dengan sistem pemerintahan mereka. Keinginan dan kebutuhan akan sebuah permulaan yang baru juga muncul karena beberapa komunitas yang berdekatan ingin bergabung bersama-sama di bawah sebuah pemerintahan baru; atau karena komunitas-komunitas itu dibebaskan memerintah diri mereka sendiri; atau karena sebuah revolusi menghancurkan masa lalu dan sebuah bentuk pemerintahan baru yang berdasarkan asas-asas baru dikehendaki; atau karena kekalahan dalam perang telah menghancurkan kelangsungan hidup pemerintahan dan diperlukan sebuah permulaan yang baru setelah perang selesai. ${ }^{7}$

Pada dasarnya tidak ada konstitusi ataupun UUD yang sama di antara negara-negara yang pernah ada di dunia. Hal ini disebabkan oleh beberapa faktor, seperti: a) Perbedaan dasar filosofis dan ideologi; b) Perbedaan landasan teori dan konsep; c) Perbedaan latar belakang kultural; d) Perbedaan latar belakang sejarah; e) Perbedaan bentuk negara, bentuk pemerintahan dan sistem pemerintahan; dan lain sebagainya. Namun meski demikian, antara berbagai konstitusi-konstitusi yang ada sebenarnya memiliki kesamaan garis besar muatannya. Bagir Manan merangkum muatan-muatan yang biasanya atau setidaknya ada di dalam sebuah konstitusi sebagai berikut: $^{8}$

1. Bentuk negara, bentuk pemerintahan, dan sistem pemerintahan.

2. Alat-alat perlengkapan negara, yang sekurang-kurangnya terdiri dari kekuasaan legislatif, eksekutif dan yudikatif (Montesquieu).

3. Cara mengisi alat perlengkapan negara dengan pejabat negara. Alat perlengkapan negara dapat diisi melalui pemilihan, pengangkatan, atau plebisit (plebiscite).

4. Hubungan antar-alat perlengkapan negara (hubungan kolegial, hubungan pengawasan, hubungan kepenasihatan, hubungan pertanggungjawaban).

5. Kekuasaan dan pembatasan kekuasaan alat-alat perlengkapan negara.

6. Hubungan antara alat perlengkapan negara dengan rakyat (hubungan mengatur, hubungan pelayanan, hubungan penjaminan dan perlindungan).

7 Wheare, hlm. 9-10.

8 Bagir Manan, Membedah UUD 1945 (Malang, Indonesia: Universitas Brawijaya Press, 2012), hlm. 8-9. 
7. Kewarganegaraan dan hak-hak kewarganegaraan (asasi dan bukan asasi).

8. Cara pembaruan UUD.

9. Aturan peralihan.

10. Dan lain-lain, seperti komisi-komisi negara.

Mengenai muatan yang terdapat di dalam konstitusi, dengan mengutip pendapat dari John Marshal, Ketua Pengadilan Amerika dari tahun 1801-1835 dan juga seorang arsitek utama Konstitusi Amerika, K.C. Wheare menuliskan dalam bukunya, bahwa agar sebuah konstitusi berisi penjelasan yang tepat terhadap semua bagian yang akan diakui oleh kekuatan-kekuatan besar, beserta semua sarana yang mereka gunakan, akan berisi kode hukum yang rinci, dan dapat diterima akal. Mungkin konstitusi itu tidak pernah dapat dipahami publik. Oleh karena itu, hanya garis besarnya saja yang perlu ditandai, hanya obyek-obyeknya yang penting yang disebutkan, dan unsur-unsur kecil yang menyusun obyek-obyek ini disimpulkan dari hakikat obyek-obyek itu sendiri. Oleh karenanya, K.C. Wheare mengatakan bahwa: “Terhadap pertanyaan: 'Apa isi konstitusi?' Jawabannya adalah: 'Sesingkat mungkin, dan yang singkat itu menjadi peraturan hukum.'”Satu karakter yang paling esensial dari sebuah bentuk konstitusi yang ideal adalah, bahwa konstitusi sesingkat mungkin. ${ }^{9}$

Sebagian besar konstitusi memiliki mukadimah. Namun meski demikian, hal mendasar yang perlu dicatat adalah, bahwa konstitusi merupakan sebuah dokumen hukum. Ia dimaksudkan untuk menyatakan aturanaturan hukum tertinggi. Karena itulah, konstitusi harus membatasi diri pada pernyataan tentang hukum, bukan opini, aspirasi, petunjuk, dan kebijakan. Di samping itu, jika konstitusi ingin menyatakan aturan-aturan hukum dan jika aturan-aturan tersebut merupakan hukum tertinggi, maka aturan-aturan ini harus singkat, umum, dan bersifat mendasar. Bahasa yang digunakan harus bersifat umum dan luas, akan tetapi pada waktu yang sama juga harus menghindari bahasa yang rancu, emosional, dan tendensius. ${ }^{10}$

9 Wheare, Konstitusi-Konstitusi Modern, hlm. 52.

10 Wheare, hlm. 77-78. 
Suatu konstitusi, Prof. Sri Soemantri dengan mengutip J.G. Steenbeek, menjelaskan bahwa pada umumnya undang-undang dasar atau konstitusi berisi tiga hal pokok, yaitu: ${ }^{11}$

1. Adanya jaminan terhadap hak-hak asasi manusia dan warga negara.

2. Ditetapkannya susunan ketatanegaraan suatu negara yang bersifat fundamental.

3. Adanya pembagian dan pembatasan tugas ketatanegaraan yang bersifat fundamental.

Pada umumnya, tujuan prinsipil dari sebuah konstitusi adalah untuk membatasi kesewenangan tindakan pemerintah, untuk menjamin hak-hak yang diperintah, dan merumuskan pelaksanaan kekuasaan yang berdaulat. Oleh karenanya, setiap konstitusi senantiasa mempunyai dua tujuan: ${ }^{12}$

1. Untuk memberikan pembatasan dan pengawasan terhadap kekuasaan politik;

2. Untuk membebaskan kekuasaan dari kontrol mutlak para penguasa, serta menetapkan bagi para penguasa tersebut batas-batas kekuasaan mereka.

\section{METODOLOGI}

Penelitian ini untuk menjawab pertanyaan apakah Shahifah Madinah layak untuk disebut sebagai sebuah konstitusi ataukah tidak. Penelitian ini merupakan penelitian normatif dengan pendekatan analisis teoritis ini mencoba menilai Shafihaf Madinah dari perspektif teori-teori konstitusi modern dengan sumber data dari dokumen sejarah dan hukum tata negara. Pendekatan yang dipakai adalah dengan Metode historis yuridis, yaitu dalam melakukan pendekatan terhadap objek yang sedang diselidiki didasarkan kepada perspektif sejarah, seperti hal lahirnya sebuah lembaga negara

11 Wheare, hlm. 60 Bandingkan pula dengan pendapat Rosco J. Tresolini dan Martin Shapiro, American Constitutional Law, yang mengatakan bahwa Konstitusi Amerika Serikat mengatur tiga masalah pokok: 1. It establishes the framework or structure of government; 2 . It delegates or assigns the power to the government; 3 . It restrains the exercise of these powers by governmental officials in order that certain individual rights can be preserved.

12 H. Dahlan Thaib, Teori Dan Hukum Konstitusi (Jakarta: PT RajaGrafindo Pesada, 2005), hlm. 24; Lihat juga: Koerniatmanto Soetoprawiro, “Konstitusi: Pengertian Dan Perkembangannya," Jurnal Pro justitia, no. 2 (1987): hlm. 31. 
tidak akan terlepas dari pengaruh kekuatan politik, kondisi politik waktu itu dan sebagainya.

\section{ISLAM DAN KONSTITUSI}

Seperti yang ditegaskan di atas, bahwa konstitusi hakikatnya adalah sebuah dokumen hukum yang dijadikan sebagai dasar hukum dalam setiap tindakan bernegara di suatu negara. Dalam konteks ini, sebenarnya di dalam ajaran Islam pun terkandung prinsip yang serupa, dimana Kitab Suci AlQuran dan Sunnah Rasul dijadikan pedoman dalam menjalankan kehidupan di dunia, termasuk salah satunya dalam hal kehidupan berbangsa dan bernegara. Al-Quran dan Sunnah juga berisi muatan-muatan hukum yang harus ditaati dan dijalankan oleh umatnya. Dan yang terpenting, prinsipprinsip seperti halnya sebuah konstitusi yang telah dijabarkan di atas, juga terkandung di dalam Al-Quran dan Sunnah. Bahkan Al-Quran dan Sunnah jauh lebih canggih dibandingkan dengan konstitusi-konstitusi, karena tidak perlu - dan bahkan tidak dapat-dirubah hanya untuk menyesuaikan dengan perkembangan zaman. Sampai kapan pun Al-Quran dan Sunnah akan tetap bersifat universal dan dapat diterapkan oleh umatnya.

Kedudukan antara Al-Quran dan Sunnah, dibandingkan dengan sebuah konstitusi dengan undang-undang, sebenarnya memiliki kedudukan yang hampir serupa. Konstitusi merupakan dasar hukum yang harus dijelaskan lebih lanjut oleh undang-undang supaya dapat diimplementasikan sebagai suatu hukum. Begitu juga dengan Al-Quran yang tidak dapat dipisahkan dari Sunnah. Salah satu tugas Sunnah adalah sebagai penjelas dari AlQuran. Al-Quran memang sudah mencakup segala macam hukum syariat secara ijmal, global. Tetapi Sunnah lah yang selanjutnya akan menjelaskan dan memperinci hukum-hukum yang bersifat ijmal tadi, supaya dapat diimplementasikan oleh umatnya.

Menurut Muhammad Abu Zuhra, setidaknya Al-Quran mengandung hukum-hukum seperti: hukum ibadah, hukum muamalat, hukum keluarga, hukum pidana, hubungan antara hakim dan yang dihukum, muamalah 
Muslim dengan sesamanya ataupun dengan non-Muslim. ${ }^{13}$

Selanjutnya dalam perkembangan khazanah fikih, hukum konstitusi pun terus dikaji lebih lanjut. Misalnya, Abdurrahman Taj dalam bukunya al-Siyasah al-Syar'iyyah wa al-Figh al-Islamiy telah memberikan definisi sebuah konstitusi, legislatif, eksekutif dan yudikatif. Menurutnya, konstitusi atau ia sebut sebagai siyasah dusturiyyah adalah peraturan dasar yang menjelaskan bentuk pemerintahan, membatasi kekuasaan, mengatur tata cara pemilihan pemerintah, membatasi kekuasaan pemerintah dalam mengatur urusan rakyat, serta mengakui hak-hak baik individu maupun kelompok. Sedangkan badan legislatif bertugas untuk membuat undang-undang dan membuat hukum yang harus diikuti pemerintah. Badan yudikatif adalah badan yang menegakkan undang-undang dan hukum tersebut. Sedangkan badan eksekutif adalah badan yang menjalankan roda pemerintahan, termasuk di dalamnya soal fiskal, administrasi maupun urusan hubungan luar negeri. ${ }^{14}$

Dalam mengatur kehidupan berbangsa dan bernegara maupun hubungan antara pemerintah dan rakyatnya, Al-Quran sendiri telah mengatur tata cara dan hukumnya. Prof. Dr. Bahauddin Mahmud Muhammad Mansur menjelaskan bahwa di dalam Al-Quran sudah terkandung konstitusi tersebut, sebagaimana firman Allah: ${ }^{15}$

“Wahai orang-orang yang beriman! Taatilah Allah dan taatilah Rasul (Muhammad), dan Ulul Amri di antara kamu. Kemudian, jika kamu berbeda pendapat tentang sesuatu, maka kembalikanlah kepada Allah (al-Quran) dan Rasul (Sunnahnya), jika kamu beriman kepada Allah dan hari kemudian. Yang demikian itu, lebih utama (bagimu) dan lebih baik akibatnya." (QS. An-Nisa: 59).

Prof. Dr. Bahauddin Mahmud Muhammad Mansur menjelaskan bahwa kandungan ayat di atas setidaknya memiliki empat unsur, yaitu Allah, Rasul, Ulil Amri (pemimpin), dan umat Muslim. Adapun bagian kedua dari ayat di atas membahas tentang perselisihan atau perkara yang dikembalikan ke-

13 Muhammad Abū Zahrah, Ushul figh (Jakarta: Pustaka Firdaus \& Perhimpunan Pengembangan Pesantren dan Masyarakat, 1999), hlm. 93.

14 Abdurahman Taj, "al-Siyasah al-Syar'iyyah wa al-Fiqh al-Islamiy," Al-Azhar, H 1434, hlm. 24.

15 Bahauddin Mahmud Muhammad Mansur, "Fiqh al-Khilafah al-Rasyidah wa al-Tahawwul alDimuqrathiy fi Mashr," Al-Azhar, H 1433, hlm. 1312. 
pada Allah dan Rasul-Nya. Yang dimaksud di sini jika perselisihan tersebut terjadi antara Ulil Amri (pemimpin) dengan rakyatnya. Dan sebagai rujukan untuk mengetahui siapa yang benar dan siapa yang telah menyeleweng adalah mengembalikan perkara tersebut kepada Allah dan Rasul-Nya. Karena Allah merupakan sumber hukum yang pertama dan utama. Dan begitu juga dengan Rasulullah, sebagaimana firman Allah: ${ }^{16}$

"Demi bintang ketika terbenam. Kawanmu (Muhammad) tidak sesat dan tidak (pula) keliru. Dan tidaklah yang diucapkannya itu (al-Quran) menurut keinginannya. Tidak lain (al-Quran) adalah wahyu yang diwahyukan (kepadanya). Yang diajarkan kepadanya oleh (Jibril) yang sangat kuat." (QS. An-Najm: 53).

Lebih lanjut Prof. Dr. Bahauddin Mahmud Muhammad Mansur menjelaskan beberapa kerangka umum yang menjadi landasan dalam interaksi sesama manusia, yaitu berasaskan pada keadilan; kasih sayang; kemurahan dan kedermawanan; menjalankan amanah kepada ahlinya; serta jika menghakimi antara manusia maka harus berlaku adil. ${ }^{17}$ Secara khusus Allah mengharamkan kepada penguasa dan pelaksana pemerintahan untuk bertindak berlebihan di luar kebenaran. ${ }^{18}$ Dalam hal harta benda dan transaksi ekonomi, Allah mengharamkan memakan harta manusia secara batil. ${ }^{19} \mathrm{Al}-$ lah juga mengharamkan bermain-main dalam takaran dan timbangan, serta merugikan atau mengurangi hak manusia untuk memakan hak-haknya

16 Mansur, "Fiqh al-Khilafah al-Rasyidah wa al-Tahawwul al-Dimuqrathiy fi Mashr."

17 QS. An-Nahl: 90, yang artinya: "Sesungguhnya Allah menyuruh (kamu) berlaku adil dan berbuat kebajikan, memberi kepada kaum kerabat, dan Allah melarang dari perbuatan keji, kemungkaran dan permusuhan. Dia memberi pengajaran kepadamu agar kamu dapat mengambil pelajara."; Dan QS. An-Nisa: 58, yang artinya: "Sesungguhnya Allah menyuruh kamu menyampaikan amanat kepada yang berhak menerimanya, dan (menyuruh kamu) apabila menetapkan hukum di antara manusia supaya kamu menetapkan dengan adil. Sesungguhnya Allah memberi pengajaran yang sebaik-baiknya kepadamu. Sesungguhnya Allah adalah Maha Mendengar dan lagi Maha Melihat."

18 QS. Al-A'raf: 33, yang artinya: “Katakanlah: 'Tuhanku hanya mengharamkan perbuatan yang keji, baik yang nampak ataupun yang tersembunyi, dan perbuatan dosa, melanggar hak manusia tanpa alasan yang benar, (mengharamkan) mempersekutukan Allah dengan sesuatu yang Allah tidak menurunkan hujjah untuk itu dan (mengharamkan) mengada-adakan terhadap Allah apa yang tidak kamu ketahui."

19 QS. Al-Baqarah: 188, yang artinya: "Dan janganlah sebahagian kamu memakan harta sebahagian yang lain di antara kamu dengan jalan yang batil dan (janganlah) kamu membawa (urusan) harta itu kepada hakim, supaya kamu dapat memakan sebahagian daripada harta benda orang lain itu dengan (jalan berbuat) dosa, padahal kamu mengetahui." 
dalam transaksi barang dan ekonomi. ${ }^{20}$ Selain itu juga dilarang menyuap hakim. ${ }^{21}$ Adapun sebagai tata cara dan kewajiban dalam berperkara (berhukum), Allah mewajibkan untuk berlaku adil dalam kesaksian. ${ }^{22}$ Dalam perkara qishash, hukuman yang diterima harus sama seperti akibat dari tindak pidananya. ${ }^{23} 24$ Semua kerangka umum dalam interaksi sesama manusia ini pada dasarnya juga menjadi landasan utama bagi bangunan konstitusi Islam.

Senada dengan di atas, dalam bukunya Fi al-Nidzam al-Siyasiy li al-Daulah al-Islamiyyah, Muhammad Salim al-'Awwa juga menjelaskan beberapa prinsip dan landasan penting dalam konstitusi Islam. Prinsip dan landasan kontitusi Islam tersebut adalah syuro, keadilan, kebebasan ${ }^{25}$, persamaan ${ }^{26}$,

20 QS. Hud: 85, yang artinya: “Dan Syu'aib berkata: 'Hai kaumku, cukupkanlah takaran dan timbangan dengan adil, dan janganlah kamu merugikan manusia terhadap hak-hak mereka, dan janganlah kamu membuat kejahatan di muka bumi dengan membuat kerusakan."

21 QS. Al-Baqarah: 188, yang artinya: "Dan janganlah sebahagian kamu memakan harta sebahagian yang lain di antara kamu dengan jalan yang batil dan (janganlah) kamu membawa (urusan) harta itu kepada hakim, supaya kamu dapat memakan sebahagian daripada harta benda orang lain itu dengan (jalan berbuat) dosa, padahal kamu mengetahui."

22 QS. Al-An'am: 152, yang artinya: “Dan janganlah kamu dekati harta anak yatim, kecuali dengan cara yang lebih bermanfaat, hingga sampai ia dewasa. Dan sempurnakanlah takaran dan timbangan dengan adil. Kami tidak memikulkan beban kepada seseorang melainkan sekedar kesanggupannya. Dan apabila kamu berkata, maka hendaklah kamu berlaku adil, kendatipun ia adalah kerabat(mu), dan penuhilah janji Allah. Yang demikian itu diperintahkan Allah kepadamu agar kamu ingat.";

QS. Al-Baqarah: 283, yang artinya: "Jika kamu dalam perjalanan (dan bermu'amalah tidak secara tunai) sedang kamu tidak memperoleh seorang penulis, maka hendaklah ada barang tanggungan yang dipegang (oleh yang berpiutang). Akan tetapi jika sebagian kamu mempercayai sebagian yang lain, maka hendaklah yang dipercaya itu menunaikan amanatnya (hutangnya) dan hendaklah ia bertakwa kepada Allah Tuhannya; dan janganlah kamu (para saksi) menyembunyikan persaksian. Dan barang siapa yang menyembunyikannya, maka sesungguhnya ia adalah orang yang berdosa hatinya, dan Allah Maha Mengetahui apa yang kamu kerjakan."

Serta QS. Al-Furqan: 72, yang artinya: "Dan orang-orang yang tidak memberikan persaksian palsu, dan apabila mereka bertemu dengan (orang-orang) yang mengerjakan perbuatan-perbuatan yang tidak berfaedah, mereka lalui (saja) dengan menjaga kehormatan dirinya."

23 QS. An-Nahl: 126, yang artinya: "Dan jika kamu memberikan balasan, maka balaslah dengan balasan yang sama dengan siksaan yang ditimpakan kepadamu. Akan tetapi jika kamu bersabar, sesungguhnya itulah yang lebih baik bagi orang-orang yang sabar."

24 Bahauddin Mahmud Muhammad Mansur, Op. Cit., hal. 1315.

25 QS. Yunus: 99, yang artinya: “Dan jika Tuhanmu menghendaki, tentulah beriman semua orang yang di muka bumi seluruhnya. Maka apakah kamu (hendak) memaksa manusia supaya mereka menjadi orang-orang yang beriman semua?"

26 QS. Al-Hujurat: 13, yang artinya: "Hai manusia, sesungguhnya Kami menciptakan kamu dari seorang laki-laki dan seorang perempuan dan menjadikan kamu berbangsa-bangsa dan bersuku-suku supaya kamu saling kenal-mengenal. Sesungguhnya orang yang paling mulia di antara kamu di sisi Allah ialah orang yang paling bertakwa di antara kamu. Sesungguhnya Allah Maha Mengetahui lagi Maha Mengenal." 
akuntabilitas pemerintah dan ketaatan terhadapnya ${ }^{27} .{ }^{28}$

Dengan demikian, sesungguhnya antara Islam dan konstitusionalisme tidak dapat dipisahkan. Islam mengakui konstitusionalisme. Di dalam Islam juga terkandung konstitusionalisme. Maka tidak benar jika ada anggapan bahwa ketatanegaraan dalam Islam melalui khilafah misalnya, merupakan bentuk totalitarianisme. Meminjam pendapat Abdul Wahab Khalaf, Nadirsyah Hosen dalam bukunya Sharia and Constitutional Reform in Indonesia menyatakan bahwa pemerintahan Islam sesungguhnya adalah pemerintahan yang konstitusional. Faktanya, pandangan syariat Islam sangat cocok (compatible) dengan paham konstitusionalisme. Setidaknya ada dua hal principal yang digariskan syariat Islam dalam mengatur ketatanegaraan, yaitu: adanya pemerintah yang dipilih melalui pemilihan (elections) atau baiat, dan; pemerintahan harus didasarkan pada syura (broad deliberation).$^{29}$

Diskursus tentang konstitusi dalam dunia Islam pun terus mengalami perkembangan. Dalam konteks kekinian misalnya, meletusnya revolusi di dunia Arab atau yang sering dikenal dengan Arab Spring pada tahun 2011 lalu ternyata membawa momentum faktual dalam diskursus konstitusi di dunia Islam. Dinamika perdebatan konstitusi Mesir pasca runtuhnya rezim Hosni Mubarak mungkin bisa menjadi studi kasus.

Revolusi Mesir memang telah membawa kita kepada kenyataan yang lebih aktual akan pandangan masyarakat terhadap syariat Islam, khususnya jika dijadikan sebagai landasan sebuah negara. Di Mesir setidaknya terdapat dua golongan besar yang berbeda secara prinsip soal syariat Islam sebagai landasan negara. Pertama, mereka yang menginginkan Islam sebagai sumber konstitusi. Kedua, mereka yang tidak menginginkan Islam sebagai sumber konstitusi, melainkan diambil dari hasil eksperimen manusia. Mengenai dua golongan ini, Prof. Dr. Bahauddin Mahmud Muhammad Mansur mengatakan:

27 QS. Shad: 26, yang artinya: "Hai Daud, sesungguhnya Kami menjadikan kamu khalifah (penguasa) di muka bumi, maka berilah keputusan (perkara) di antara manusia dengan adil dan janganlah kamu mengikuti hawa nafsu, karena ia akan menyesatkan kamu dari jalan Allah. Sesungguhnya orang-orang yang sesat dari jalan Allah akan mendapat azab yang berat, karena mereka melupakan Hari Perhitungan."

28 Muhammad Salim 'Awwa, Fi Al-Nizam Al-Siyasi Li Al-Dawlah Al-Islamiyah (Qahirah: : Maktab al-Misri al-Hadith, 1983), hlm. 181, 207, 212, 226, dan 230. 45-47.

29 Nadirsyah Hosen, Shari'a E Constitutional Reform in Indonesia (Singapore: ISEAS, 2007), hlm. 
"Asas nilai atau norma yang ada pada rakyat Arab umumnya, dan pada rakyat Mesir khususnya, bersumber pada agama Samawi yang ditutup dengan agama Islam. Akan tetapi mereka yang menentang agama Islam untuk dijadikan sebagai sumber konstitusi, takut akan berpegang teguh pada nas-nas yang ada di al-Quran dan Sunnah Nabawi. Namun sayangnya ketakutan itu tanpa diiringi dengan upaya atau target untuk memurnikan makna nas atau konteks realita. Di samping itu, juga ada kelompok yang berpegang teguh pada perkataan salafus shalih dan fatwa-fatwa mereka, serta menganggap hal tersebut adalah kewajiban dalam agama. Namun sayangnya juga, mereka tidak melihat apakah hal itu mungkin untuk diterapkan di adab ke-21. Bahkan mereka masih berpegang teguh juga pada perkataan salafus shalih tersebut, meski hasilnya tidak sesuai dengan kondisi setelahnya." ${ }^{\prime 30}$

Gambaran kedua golongan ini sangat jelas sekali mewarnai kehidupan politik Mesir pasca revolusi, bahkan hingga usai pemilihan umum, baik legislatif maupun presiden. Kemenangan Ikhwanul Muslimin dan kelompok Salafi Mesir dalam Pemilu legislatif, yang berujung pada munculnya desasdesus akan dijadikannya Al-Quran dan Sunnah sebagai konstitusi negara, ternyata menjadi ketakutan tersendiri bagi kalangan sekuler dan sebagian rakyat Mesir lainnya. Parlemen yang mayoritas dikuasai oleh kelompok Islam ini dianggap sebagai ancaman besar terhadap konstitusi dan undangundang Mesir. Akhirnya, Dewan Tertinggi Militer-yang berkuasa pada masa transisi-membubarkan Parlemen melalui Mahkamah Konstitusi, tanpa alasan yang jelas.

\section{NASKAH SHAHIFAH MADINAH}

Naskah Shahifah Madinah tergolong salah satu naskah sejarah yang sangat tua. Diperkirakan naskah itu telah ada pada abad ke-7 Masehi, yakni di masa awal-awal Islam. Meskipun di kalangan ulama dan sejarawan sendiri memang terdapat perbedaan pendapat soal kapan tepatnya Shahifah Madinah ini dibuat. Shubhi al-Shalih dalam bukunya 'Ulum al-Hadis wa

30 Mansur, “Fiqh al-Khilafah al-Rasyidah wa al-Tahawwul al-Dimuqrathiy fi Mashr.” 
Mushthalahuhu mengatakan bahwa naskah tersebut dilakukan pada tahun pertama Hijriyah, yaitu di masa awal-awal hijrah Rasulullah SAW dari Makkah ke Madinah. ${ }^{31}$ Sementara Ahmad Ibrahim al-Syarif menegaskan bahwa penulisan itu terjadi sebelum habis tahun pertama Hijrah. ${ }^{32}$ Sementara itu alThabari mengatakan bahwa Shahifah Madinah tersebut dibuat ketika Nabi Muhammad SAW baru berdiam di Madinah, yakni pada bulan Syawal tahun ke-2 Hijriyah. ${ }^{33}$ Sehingga sangat penting kiranya memaparkan otentisitas naskah Shahifah Madinah ini sebelum mengkajinya lebih lanjut.

Mengutip dari Arent Jan Wensinck dalam bukunya Mohammed en de Joden te Medina, Ahmad Sukardja menyebutkan bahwa petunjuk penting tentang Shahifah Madinah dapat ditelusuri dari sejumlah Hadis. Imam alBukhari dan Imam Muslim telah mencantumkan ikhtisar tentang Shahifah Madinah ini di dalam Bab Fada'il al-Madinah. Abu Dawud dan al-Nasa'i juga menyebutkannya. Misalnya di dalam Hadis yang diriwayatkan oleh al-Bukhari dan Abu Dawud disebutkan bahwa, ketika Rasulullah SAW tiba di Madinah, dilihat dari segi agama, penduduk Madinah terdiri dari tiga golongan besar, yaitu: Muslimin ${ }^{34}$, Musyrikin ${ }^{35}$ dan Yahudi ${ }^{36}$. Di tengah kemajemukan penghuni Kota Madinah itulah, Nabi Muhammad SAW berusaha membangun tatanan hidup bersama, mencakup semua golongan yang ada di Kota Madinah. Salah satu langkah awal sekali yang dilakukan Rasullah SAW adalah mempersaudarakan antara golongan Muhajirin dan Anshar. ${ }^{37}$

31 Shubhi Al-Shalih, 'Ulum al-Hadis wa Mushthalahuhu (Bairut: Dar Al-Ilm Lil Malayin, 1977), hlm. 145; Ahmad Sukardja dan Ahmad Sukardja, Piagam Madinah E Undang-Undang Dasar 1945 Nri 1945: Kajian Perbandingan Tentang Dasar Hidup Bersama Dalam Masyarakat Yang Majemuk (Rawamangun, Jakarta: Sinar Grafika, 2012), hlm. 42 Lihat juga:

32 Ahmad Ibrahim Al-Syarif, Dawlah al-Rasul fi al-Madinah (Kuwait: Dar al-Bayan, 1972), hlm. 89; Lihat juga: Sukardja dan Sukardja, Piagam Madinah \& Undang-Undang Dasar 1945 Nri 1945.

33 Nawāf Ṭabarī, Tārìkh Al-Ṭabarī: Tārìkh Al-Umam Wa-Al-Mulūk, al-Ṭab‘ah 1. (Bayrūt: Dār Ṭādir, 1987), hlm. 84-85.

34 Kaum Muslimin terdiri dari dua golongan, yaitu: Muhajirin, yang merupakan pendatang atau yang hijrah dari Makkah ke Madinah; dan Anshar, yang merupakan penduduk Madinah asli yang sudah memeluk Islam dan menerima/menolong hijrahnya golongan Muhajirin di Madinah. Golongan Muhajirin adalah orang-orang Quraisy yang telah masuk Islam yang terdiri dari beberapa kelompok, di antaranya Bani Hasyim dan Bani Muthalib. Sedangkan golongan Anshar terdiri dari kabilah utama seperti kabilah 'Aws dan Khazraj. Setiap kabilah ini terdiri dari kelompok suku yang banyak.

35 Golongan Musyrikin adalah orang-orang Arab yang masih menyembah berhala (paganisme).

36 Golongan Yahudi terdiri dari keturunan Yahudi pendatang dan keturunan Arab yang masuk agama Yahudi atau kawin dengan orang Yahudi pendatang. Tiga kelompok besar keturunan Yahudi pendatang adalah Bani Nadir, Bani Qainuqa dan Bani Quraizhah.

37 Sukardja dan Sukardja, Piagam Madinah E Undang-Undang Dasar 1945 Nri 1945, hlm. 36. 
Tentang keberadaan Shahifah Madinah ini, Imam al-Bukhari dalam Shahih-nya meriwayatkan: Abu Juhaifah bertanya kepada Ali RA, "Apakah ada wahyu selain dalam Kitab Allah?" Jawab Ali: "Saya tidak mengetahui kecuali faham yang diberikan Allah dalam al-Quran dan apa yang ada dalam shafihah ini." "Apa yang ada di dalam shahifah ini?" Jawab Ali: “Tentang diat, tebusan tawanan, dan seorang Muslim tidak dibunuh lantaran membunuh orang kafir." ${ }^{38}$ Hadis dengan makna yang serupa dari Ali RA juga diriwayatkan dengan jalur sanad yang lain.

Ibnu Ishaq mengutarakan naskah lengkap Shahifah Madinah, sebagaimana dikutip sepenuhnya oleh Ibnu Hisyam di dalam kitabnya Sirah alNabiy. Sayangnya Ibnu Ishaq tidak menjelaskan dari siapa atau bagaimana ia menerima naskah itu. Ia hanya memberikan keterangan singkat bahwa Rasullah SAW telah membuat shahifah antara Muhajirin dan Anshar, dan ia mengikat perjanjian perdamaian dengan Yahudi. Di dalam perjanjian itu dinyatakan bahwa mereka bebas dalam agama mereka dan harta mereka dilindungi. Ia menetapkan syarat (kewajiban) yang harus mereka penuhi dan syarat (hak) bagi mereka. ${ }^{39}$

Selain itu, Abu ‘Ubayd al-Qasim Ibnu Sallam, ulama yang hidup semasa Ibnu Hisyam, juga meriwayatkan naskah Shahifah Madinah secara lengkap seperti yang ditulis oleh Ibnu Hisyam. Namun bedanya, Abu ‘Ubayd mencantumkan sanad dari siapa ia menerima naskah itu. Ia menerima naskah itu dari dua orang: Yahya bin 'Abdullah bin Bakir dan 'Abdullah bin Shalih. Keduanya menerima naskah itu dari al-Lays bin Sa'ad. Al-Lays dari ‘Uqail bin Khalid, dan ‘Uqail dari Ibnu Syihab (al-Zuhriy). Ibnu Syihab, seorang di antara Tabi'in besar, mengatakan bahwa, "Rasulullah SAW menulis naskah ini." 40 Ibnu Sallam meriwayatkan naskah itu selengkap yang diriwayatkan oleh Ibnu Hisyam dari Ibnu Ishaq.

Maka dengan demikian, mulai dari Hadis riwayat Imam al-Bukhari yang menyatakan adanya Shahifah tersebut, lalu adanya naskah lengkap

38 Sukardja dan Sukardja, hlm. 37 Lihat juga: Imam al-Bukhari, Shahih al-Bukhari, juz 4, hal. 84. Sanad hadis ini: al-Bukhari dari Ahmad bin Yunus, dari Zuhayr, dari Mutharrif, dari 'Amir, dari Abi Juhaifah, dari Ali RA.

39 Sukardja dan Sukardja, hlm. 37 Lihat juga: Ibnu Hisyam, Sirah al-Nabiy, juz 2 (t. tp: Dar al-Fikr, 1981), hal. 119.

40 Abu ‘Ubayd al-Qasim Ibnu Sallam, Kitab al-Amwal (Kairo: Dar al-Fikr, 1975), hlm. 260-266; lihat juga: Sukardja dan Sukardja, Piagam Madinah \& Undang-Undang Dasar 1945 Nri 1945. 
yang diutarakan oleh Ibnu Ishaq tanpa sanad, dan terakhir naskah lengkap yang ditulis oleh Ibnu Sallam dengan sanad, menandakan bahwa hubungan tersebut saling menguatkan akan keberadaan Shahifah Madinah itu. Maka otentisitas naskah Shahifah Madinah tersebut sudah tidak dapat diragukan lagi.

Adapun naskah atau isi dari Shahifah Madinah adalah sebagai berikut: ${ }^{41}$

"Dengan nama Allah Yang Maha Pengasih dan Maha Penyayang" Ini adalah Piagam dari Muhammad, Nabi Saw., di kalangan mukminin dan muslimin (yang berasal) dari Quraisy dan Yasrib, dan orang yang mengikuti mereka, menggabungkan diri dan berjuang bersama mereka.

1. Sesungguhnya mereka satu umat, lain dari (komunitas) manusia yang lain.

2. Kaum Muhajirin dari Quraish sesuai keadaan (kebiasaan) mereka, bahu membahu membayar diat di antara mereka dan membayar tebusan tawanan dengan cara yang baik dan adil di antara mukminin.

3. Bani 'Awf, sesuai keadaan (kebiasaan) mereka, bahu-membahu membayar diat di antara mereka seperti semula, dan setiap suku membayar tebusan tawanan dengan baik dan adil di antara mukminin.

4. Bani Sa'idah, sesuai keadaan (kebiasaan) mereka, bahu membahu membayar diat di antara mereka (seperti) semula dan setiap suku membayar tebusan tawanan dengan cara yang baik dan adil di antara mukminin.

5. Bani al-Hars, sesuai keadaan (kebiasaan) mereka, bahu membahu membayar diat di antara mereka (seperti) semula dan setiap suku membayar tebusan tawanan dengan cara yang baik dan adil di antara mukminin.

41 Sukardja dan Sukardja, Piagam Madinah \& Undang-Undang Dasar 1945 Nri 1945, hlm. 47-57. 
6. Bani Jusyam, sesuai keadaan (kebiasaan) mereka, bahu membahu membayar diat di antara mereka (seperti) semula dan setiap suku membayar tebusan tawanan dengan cara yang baik dan adil di antara mukminin.

7. Bani al-Najjar, sesuai keadaan (kebiasaan) mereka, bahu membahu membayar diat di antara mereka (seperti) semula dan setiap suku membayar tebusan dengan cara yang baik dan adil di antara mukminin.

8. Bani 'Amr bin 'Awf, sesuai keadaan (kebiasaan) mereka, bahu membahu membayar diat di antara mereka (seperti) semula dan setiap suku membayar tebusan tawanan dengan cara yang baik dan adil di antara mukminin.

9. Bani al-Nabit, sesuai keadaan (kebiasaan) mereka, bahu membahu membayat diat di antara mereka (seperti) semula dan setiap suku membayat tebusan tawanan dengan cara yang baik dan adil di antara mukminin.

10. Bani al-'Aws, sesuai keadaan (kebiasaan) mereka, bahu membahu membayar diat di antara mereka (seperti) semula dan setiap suku membayar tebusan tawanan dengan cara yang baik dan adil di antara mukminin.

11. Sesungguhnya mukminin tidak boleh membiarkan orang yang berat menanggung utang di antara mereka, tetapi membantunya dengan baik dalam pembayaran tebusan atau diat.

12. Seorang mukmin tidak dibolehkan membuat persekutuan dengan sekutu mukmin lainnya, tanpa persetujuan daripadanya.

13. Orang-orang mukmin yang takwa harus menentang orang yang di antara mereka mencari atau menuntut sesuatu secara dhalim, jahat, melakukan permusuhan atau kerusakan di kalangan mukminin. Kekuatan mereka bersatu dalam menentangnya, sekalipun ia anak dari salah seorang di antara mereka.

14. Seorang mukmin tidak boleh membunuh orang beriman lainnya lantaran (membunuh) orang kafir, tidak boleh pula orang mukmin membantu orang kafir untuk (membunuh) orang beriman. 
15. Jaminan Allah satu. Jaminan (perlindungan) diberikan oleh mereka yang dekat. Sesungguhnya mukmin itu saling membantu, tidak tergantung pada golongan lain.

16. Sesungguhnya orang Yahudi yang mengikuti kita berhat atas pertolongan dan santunan, sepanjang (mukmin) tidak terzalimi dan ditentang (olehnya).

17. Perdamaian mukminin adalah satu. Seorang mukmin tidak boleh membuat perdamaian tanpa ikut serta mukmin lainnya di dalam suatu peperangan di jalan Allah, kecuali atas dasar kesamaan dan keadilan di antara mereka.

18. Setiap pasukan yang berperang bersama kita harus bagu membahu satu sama lain.

19. Orang-orang mukmin itu membalas pembunuhan mukmin lainnya dalam peperangan di jalan Allah. Orang-orang beriman dan bertakwa berada pada petunjuk yang terbaik dan lurus.

20. Orang musyrik (yasrib) dilarang melindungi harta dan jiwa orang (musyrik) Quraisy, dan tidak boleh campur tangan melawan orang beriman.

21. Barang siapa membunuh orang beriman dan cukup bukti atas perbuatannya, harus dihukum bunuh, kecuali wali si terbunuh rela (menerima diat). Segenap orang beriman harus bersatu dalam menghukumnya.

22. Tidak dibenarkan bagi orang mukmin yang mengakui piagam ini, percaya kepada Allah dan hari Akhir, untuk membantu pembunuh dan memberi tempat kediaman kepadanya. Siapa yang memberi bantuan atau menyediakan tempat tinggal bagi pelanggar itu, akan mendapat kutukan dan kemurkaan Allah di hari kiamat, dan tidak diterima daripadanya penyesalan dan tebusan.

23. Apabila kamu berselisih tentang sesuatu, penyelesaiannya menurut (ketentuan) Allah dan (keputusan) Muhammad SAW.

24. Kaum Yahudi memikul biaya bersama mukminin selama dalam peperangan.

25. Kaum Yahudi dari Bani 'Awf adalah satu umat dengan mukminin. Bagi kaum Yahudi agama mereka, dan bagi kaum muslimin agama 
mereka. Juga (kebebasan ini berlaku) bagi sekutu-sekutu dari diri mereka sendiri, kecuali bagi yang zalim dan jahat. Hal demikian akan merusak diri dan keluarganya.

26. Kaum Yahudi Bani Najjar diperlakukan sama seperti Yahudi Bani ‘Awf.

27. Kaum Yahudi Bani Hars diperlakukan sama seperti Yahudi Bani 'Awf.

28. Kaum Yahudi Bani Sa'idah diperlakukan sama seperti Bani ‘Awf.

29. Kaum Yahudi Bani Jusyam diperlakukan sama seperti Yahudi Bani 'Awf.

30. Kaum Yahudi Bani al-'Aws diperlakukan sama seperti Yahudi Bani 'Awf.

31. Kaum Yahudi Bani Sa'labah diperlakukan sama seperti Yahudi Bani ‘Awf. Kecuali orang zalim aatau khianat. Hukumannya hanya menimpa diri dan keluarganya.

32. Suku Jafnah dari Sa'labah (diperlakukan) sama seperti mereka (Bani Sa'labah).

33. Bani Syuthaybah (diperlakukan) sama seperti Yahudi Bani 'Awf. Sesungguhnya kebaikan (kesetiaan) itu lain dari kejahatan (khianat).

34. Sekutu-sekutu Sa'labah (diperlakukan) sama seperti mereka (Bani Sa'labah).

35. Kerabat Yahudi (di luar kota Madinah) sama seperi mereka (Yahudi).

36. Tidak seorang pun dibenarkan ke luar (untuk berperang), kecuali seizin Muhammad SAW. Ia tidak boleh dihalangi (menuntut pembalasan) luka (yang dibuat orang lain). Siapa berbuat jahat (membunuh), maka balasan kejahatan itu akan menimpa diri dan keluarganya, kecuali ia teraniaya. Sesungguhnya Allah sangat membenarkan (ketentuan) ini.

37. Bagi kaum Yahudi ada kewajiban biaya, dan bagi kaum muslimin ada kewajiban biaya. Mereka (Yahudi dan muslimin) bantu membantu dalam menghadapi musuh warga piagam ini. Mereka saling memberi saran dan nasihat. Memenuhi janji lawan dari khianat. Se- 
seorang tidak menanggung hukuman akibat (kesalahan) sekutunya. Pembelaan diberikan kepada pihak yang teraniaya.

38. Kaum Yahudi memikul biaya bersama mukminin selama dalam peperangan.

39. Sesungguhnya Yasrib itu tanahnya "haram" (suci) bagi warga piagam ini.

40. Orang yang mendapat jaminan (diperlakukan) seperti diri penjamin, sepanjang tidak bertindak merugikan dan tidak khianat.

41. Tidak boleh jaminan diberikan, kecuali seizin ahlinya.

42. Bila terjadi suatu peristiwa atau perselisihan di antara pendukung piagam ini, yang dikhawatirkan menimbulkan bahwa, diserahkan penyelesaiannya menurut (ketentuan Allah dan (keputusan) Muhamma SAW). Sesungguhnya Allah paling memelihara dan memandang baik isi piagam ini.

43. Sungguh tidak ada jaminan perlindungan bagi Quraisy (Makkah) dan juga bagi pendukung mereka.

44. Mereka (pendukung piagam) bahu membahu dalam menghadapi penyerang kota Yasrib.

45. Apabila mereka (pendukung piagam) diajak berdamai dan mereka (pihak lawan) memenuhi perdamaian serta melaksanakan perdamaian itu, maka perdamaian itu harus dipatuhi. Jika mereka diajak berdamai seperti itu, kaum mukminin wajib memenuhi ajakan dan melaksanakan perdamaian itu, kecuali terhadap orang yang menyerang agama. Setiap orang wajib melaksanakan (kewajiban) masingmasing sesuai tugasnya.

46. Kaum Yahudi al 'Aws, sekutu dan diri mereka memilih hak dan kewajiban seperti kelompok lain pendukung piagam ini, dengan perlakuan yang baik dan penuh dari semua pendukung piagam ini. Sesungguhnya kebaikan (kesetiaan) itu berbeda dari kejahatan (pengkhianatan). Setiap orang bertanggung jawab atas perbuatannya.

47. Sesungguhnya piagam ini tidak membela orang zalim dan khianat. Orang yang keluar (bepergian) aman, dan orang berada di Madinah aman, kecuali orang yang zalim dan khianat. Allah adalah penjamin orang yang berbuat baik dan takwa. Muhammad Rasulullah SAW. 


\section{ATURAN KEHIDUPAN BERNEGARA DALAM SHAHIFAH MADINAH}

Di atas telah disinggung bahwa Kota Madinah ketika awal hijrahnya Rasulullah SAW setidaknya terdiri dari tiga golongan besar, yaitu kaum Muslimin, Musyrik dan Yahudi. Setiap golongan besar tersebut masih terdiri dari berbagai kelompok lainnya lagi. Artinya, kondisi Kota Madinah ketika itu merupakan kota dengan masyarakat yang pluralis. Jadi, di tengah kondisi masyarakat yang pluralis itulah Nabi Muhammad SAW mendirikan sebuah negara baru, yaitu Negara Madinah.

Jika merujuk pada syarat-syarat politis berdirinya suatu negara yaitu pemerintahan, rakyat dan wilayah, maka Kota Madinah sejatinya sudah memenuhi kriteria sebagai sebuah negara. Di Madinah terdapat pemerintahan yang langsung di bawah Rasullah SAW yang bertindak layaknya seorang kepala negara. Di Madinah juga terdapat rakyat yang diperintah, yakni berupa masyarakat majemuk. Dan di Madinah juga sudah memiliki batas teritorial yang jelas ketika itu, atau yang biasa disebut dengan tanah Haram.

Jika merujuk kepada teori asal usul sebuah konstitusi seperti yang telah dijelaskan oleh K.C. Wheare di atas, maka masyarakat Madinah pun telah memenuhi kriteria membentuk suatu negara yang berlandaskan pada konstitusi. Wheare menjelaskan bahwa asal usul sebuah konstitusi dibentuk sebagai dasar negara karena adanya kesepakatan rakyat untuk membuat permulaan yang baru. Sebuah permulaan yang baru salah satunya bisa disebabkan keinginan untuk bergabung bersama-sama di bawah sebuah pemerintahan baru. Dengan adanya Shahifah Madinah, ini menandakan bahwa masyarakat Madinah ketika itu telah memutuskan untuk memulai kehidupan yang baru di bawah pemerintahan yang dipimpin oleh Rasullah SAW. Shahifah Madinah setidaknya dijadikan landasan kesepakatan atas hal itu.

Hans Kelsen berpendapat bahwa negara itu merupakan kesatuan tata hukum. Menurutnya, negara itu identik dengan hukum. ${ }^{42}$ Maka jika merujuk kepada pendapat ini, sesungguhnya Madinah melalui Shahifah Madinah sudah pantas untuk disebut sebagai negara. Karena di dalam Shahifah

42 Sjachran Basah, Ilmu Negara (pengantar, Metode, Dan Sejarah Perkembangan) (Bandung: PT. Citra Aditya Bakti, 1987), hlm. 160. 
Madinah terkandung tata hukum yang harus ditaati bersama oleh mereka yang mengakuinya.

Di dalam Shahifah Madinah telah disebutkan secara eksplisit tertulis beberapa nama golongan dan berbagai suku. Ini menandakan bahwa tampaknya Nabi Muhammad SAW mempunyai pengetahuan yang luas tentang keadaan dan politik kelompok-kelompok itu. Karena pada mulanya masing-masing kelompok hidup secara terpisah, maka tidak ada persatuan di antara mereka, dan mereka tidak mumpunyai pemerintah yang menaungi berbagai kelompok itu. ${ }^{43}$

Jika kita kaji muatan materi Shahifah Madinah secara mendalam kemudian dibandingkan dengan konstitusi UUD RI 1945, kita akan mendapat gambaran tentang karakteristik masyarakat dan Negara Madinah pada masa-masa awal kelahiran dan perkembangannya: ${ }^{4}$

1. Masyarakat pendukung piagam ini adalah masyarakat majemuk yang terdiri atas berbagai suku dan agama. Konstitusi Madinah secara tegas mengakui eksistensi suku bangsa dan agama dan memelihara unsur solidaritasnya. Konstitusi Madinah menggariskan kesetiaan kepada masyarakat yang lebih luas lebih penting dariapada kesetiaan yang sempit kepada suku, dengan mengalihkan perhatian suku-suku itu pada pembangunan negara, yang warga negaranya bebas dan merdeka dari pengaruh dan kekuasaan manusia lainnya (pasal 1). Adapun tali persatuannya adalah politik dalam rangka mencapai cita-cita bersama (pasal 17, 23, dan 42). Bandingkan dengan Pasal 1 ayat (1) UUD 45 dan Alinea IV Pembukaan UUD 45 "cita-cita nasional adalah mewujudkan masyarakat yang adil dan makmur".

2. Semua warga negara mempunyai kedudukan yang sama, wajib saling menghormati dan wajib kerja sama antara sesama mereka, serta tidak seorang pun yang diperlakukan secara buruk (pasal 12, 16). Bahkan orang yang lemah di antara mereka harus dilindungi dan dibantu (pasal 11). Bandingkan dengan UUD 45 Pasal ayat (1) "semua warga negara mempunyai kedudukan yang sama di dalam hukum dan pemerintah- 
an...". Dan Pasal 34 UUD 45 menegaskan "fakir miskin dan anak terlantar dipelihara oleh negara".

3. Negara mengakui, melindungi, dan menjamin kebebasan menjalankan ibadah dan agama baik bagi orang-orang muslim maupun nonMuslim (pasal 25-33). Bandingkan dengan Pasal 29 ayat (2) UUD 45 "negara menjamin kemerdekaan tiap-tiap penduduk untuk memeluk agamanya masing-masing dan beribadat menurut agamanya dan kepercayaannya itu".

4. Setiap warga negara mempunyai kedudukan yang sama di depan hukum (pasal 34, 40). Bandingkan dengan Pasal 27 UUD 45 “setiap warga negara bersamaan kedudukannya di dalam hukum...".

5. Hukum adat (kelaziman mereka pada masa lalu), dengan berpedoman pada kebenaran dan keadilan, tetap diberlakukan (pasal 2, 10, 21). Bandingkan dengan UUD 45 Pasal 18 tentang pemerintahan daerah “...dengan memandang dan mengingat dasar permusyawaratan dalam sistem pemerintahan negara, dan hak-hak asal-usul dalam daerah-daerah yang bersifat istimewa". Dan Pasal 32 UUD 45 "pemerintah memajukan kebudayaan nasional Indonesia”. Penjelasan Pasal 32 UUD 45 “...kebudayaan lama dan asli yang terdapat di daerah-daerah di seluruh Indonesia terhitung sebagai kebudayaan bangsa".

6. Semua warga negara mempunyai hak dan kewajiban yang sama terhadap negara. Mereka berkewajiban membela dan mempertahankan negara dengan harta, jiwa mereka dan mengusir setiap aggressor yang mengganggu stabilitas negara (pasal 24, 36, 37, 38). Bandingkan dengan UUD 45 Pasal 30 ayat (1) "tiap-tiap warga negara berhak dan wajib ikut serta dalam usaha pembelaan negara".

7. Sistem pemerintahan adalah desentralisasi, dengan Madinah sebagai pusatnya (pasal 39). Bandingkan dengan UUD 45 Pasal 18 "pembagian daerah Indonesia atas dasar besar dan kecil dengan bentuk susunan pemerintahannya ditetapkan dengan undang-undang".

Dengan demikian, dari sebanyak 47 pasal Shahifah Madinah beserta kandungannya di atas, terlihat beberapa gambaran tentang prinsip-prinsip negara modern pada masa awal kelahiran Negara Madinah dimana Nabi 
Muhammad SAW sebagai kepala negara, dan warganya terdiri dari berbagai macam aliran, golongan, keturunan, budaya, maupuan agama yang dianutnya.

\section{SHAHIFAH MADINAH SEBAGAI KONSTITUSI?}

Penyebutan Shahifah Madinah sebagai konstitusi atau bukan, memang mengalami beberapa perdebatan dan perbedaan pendapat di kalangan ahli. Hal ini lumrah adanya jika dilihat dari beberapa faktor, di antaranya: Shahifah Madinah merupakan naskah kuno yang berusia cukup lama; adanya perkembangan teori dan paham konstitusionalisme seiring dengan modernisasi; maupun perbedaan latar belakang pemahaman dari para ahli dalam menilai Shahifah Madinah.

Shahifah Madinah sendiri sebetulnya memang dapat masuk ke dalam beberapa kategori sebuah dokumen. Misalnya, beberapa ahli memberikan nama-nama yang berbeda kepada Shahifah Madinah. Ada yang menyebutnya "perjanjian" (trety), karena nabi membuat perjanjian perhabatan antara Muhajirin dan Ansar sebagai komunitas Islam di satu pihak dan antara kaum muslimin dan kaum Yahudi serta suku-suku mereka di pihak lain agar mereka terhindat dari pertentangan suku serta bersama-sama mempertahankan keamanan kota Madinah dari serangan musuh untuk hidup berdampingan secara damai. Disebut "piagam" (charter), karena isinya mengakui hak-hak kebebasan beragam dan berkeyakinan, kebebasan berpendapat dan kehendak umum warga Madinah supaya keadilan terwujud dalam kehidupan mereka, mengatur kewajiban-kewajiban kemasyarakatan semua golongan, menetapkan pembentukan persatuan dan kesatuan semua warga dan prinsip-prinsipnya untuk menghapuskan tradisi dan peraturan kesukuan yang tidak baik. Disebut "konstitusi" (constitution), karena di dalamnya terdapat prinsip-prinsip untuk mengatur kepentingan umum dan dasar-dasar sosial politik yang bekerja untuk membentuk suatu masyarakat dan pemerintahan sebagai wadah persatuan penduduk Madinah yang majemuk tersebut. ${ }^{45}$

Akan tetapi, baik disebut sebagai "perjanjian" maupun "piagam", dan "konstitusi" bentuk dan muatan Shahifah Madinah itu tidak menyimpang

45 Thaib, hlm. 44. 
dari pengertian ketiga istilah tersebut. Semua karakteristik dari klasifikasi dokumen tersebut memang terkandung di dalam Shahifah Madinah. Karenanya tidak salah jika Marduke Pickthal, H.A.R. Gibb, Wensinck, dan Watt menyebut Shahifah Madinah tersebut sebagai konstitusi. ${ }^{46}$

Dari sisi konstitusi, Shahifah Madinah sebenarnya telah mencakup syarat-syarat fundamental sebuah konstitusi. Mulai dari asal usul pembentukannya hingga kandungan isi di dalamnya. Hubungan antara Islam dan konstitusi seperti yang telah dipaparkan di atas, semakin memperkuat bahwa sesungguhnya, bisa jadi yang dikehendaki oleh Rasulullah SAW dan masyarakat Madinah dari Shahifah ketika itu adalah sebuah konstitusi. Pasalnya, prinsip-prinsip sebuah konstitusi bukanlah sesuatu yang asing bagi Rasulullah SAW dan masyarakat Madinah. Hanya saja penyebutannya secara teoritis dan secara ilmu pengetahuan belum ada ketika itu. Perkara ini sama halnya dengan perkara Ilmu Usul Fikih. Sejatinya Usul Fikih sudah ada sejak zaman Rasulullah SAW. Akan tetapi Usul Fikih baru dikodifikasi sebagai ilmu pengetahuan baru setelah Imam al-Syafi'i menuliskan kitabnya yang berjudul al-Risalah.

C.F. Strong menjelaskan bahwa pada dasarnya tujuan konstitusi politik adalah sama, di manapun ia berada, yaitu melindungi kemajuan dan perdamaian sosial, mengamankan hak-hak individu, dan memajukan kesejahteraan nasional. ${ }^{47}$ Artinya, Shahihaf Madinah yang di dalamnya juga telah mengatur perkara-perkara yang menjadi tujuan konstitusi itu juga layak dan pantas untuk disebut sebagai sebuah konstitusi. Meskipun dalam konteks konstitusi modern, masih ada aspek-aspek prinsip konstitusi yang masih belum tercantum di dalam Shahifah Madinah.

\section{KESIMPULAN}

Dari pemaparan di atas, ternyata menunjukkan bahwasannya Islam memang agama yang universal yang selalu sesuai dengan perkembangan zaman. Dalam konteks kehidupan politik berbangsa dan bernegara, ternyata Islam memiliki konsep-konsep dan prinsip-prinsip yang sesuai dengan

46 Thaib, hlm. 45.

47 Strong, Konstitusi-Konstitusi Politik Modern, hlm. 74. 
perkembangan konstitusionalisme. Dalam mengatur sebuah negara dan kehidupan di dalamnya, Islam sudah memiliki garis-garis besar dasar hukum yang harus ditaati. Nabi Muhammad SAW bahkah telah mencontohkannya secara langsung melalui Negara Madinah yang didirikannya bersama masyarakat Madinah. Sehingga, konsep Islam dalam ketatanegaraan sejatinya bukanlah sesuatu yang bertentangan dengan semangat konstitusionalisme. Dengan kata lain, Islam tidak pernah mengajarkan prinsip negara yang diktator atau totalitarianisme. Negara Islam merupakan negara yang konstitusionalis.

Terkait dengan Shahifah Madinah yang menjadi bukti otentik atas berdirinya Negara Madinah, memang layak jika disebut dengan sebuah konstitusi. Substansi konstitusionalisme sudah terkandung sangat jelas di dalam Shahifah Madinah. Aturan-aturan yang mendasar dalam kehidupan berbangsa dan bernegara tertulis secara eksplisit di dalam 47 pasal Shahifah Madinah. Meskipun memang harus diakui, jika dibandingkan dengan konstitusi modern, Shahifah Madinah masih belum lengkap. Misalnya, Shahifah Madinah tidak mencantumkan lembaga-lembaga negara tertentu dalam menjalankan pemerintahan, tidak ada pembatasan kekuasaan pemerintah, tidak ada aturan perubahan, dan lainnya. Namun setidaknya, substansi utama dari konstitusionalisme sudah ada dalam Shahifah Madinah. Karena pada dasarnya, konstitusi tidak mungkin dapat memuat segala aturan dalam suatu negara. Konstitusi hanyalah memuat garis-garis besar aturan yang pokok saja. Dan hal ini tentu saja disesuaikan dengan kebutuhan negara dalam konteks tertentu.

Shahifah Madinah dapat menjadi contoh betapa sebuah konstitusi memang betul-betul mutlak diperlukan bagi sebuah negara. Apapun bentuk negaranya. Karena konstitusi merupakan dasar hukum bagi sebuah negara. Namun demikian, meski Islam - seperti yang telah dicontohkan oleh Rasulullah-mengamini diperlukan/keniscayaan sebuah negara, akan tetapi negara bukanlah suatu tujuan. Negara tidak lebih hanya sebagai sebuah fasilitator untuk dapat menegakkan syariat Allah yang telah diturunkan kepada manusia. Artinya, konstitusi dan negara bukanlah sesuatu yang menjadi harga mati. Keduanya dapat berubah sesuai dengan perkembangan zaman. Wallahu'alam.[] 


\section{DAFTAR PUSTAKA}

Abū Zahrah, Muhammad. Ushul figh. Jakarta: Pustaka Firdaus \& Perhimpunan Pengembangan Pesantren dan Masyarakat, 1999.

Al-Shalih, Shubhi. 'Ulum al-Hadis wa Mushthalahuhu. Bairut: Dar Al-Ilm Lil Malayin, 1977.

Al-Syarif, Ahmad Ibrahim. Dawlah al-Rasul fi al-Madinah. Kuwait: Dar alBayan, 1972.

'Awwa, Muhammad Salim. Fi Al-Nizam Al-Siyasi Li Al-Dawlah Al-Islamiyah. Qahirah: : Maktab al-Misri al-Hadith, 1983.

Basah, Sjachran. Ilmu Negara (pengantar, Metode, Dan Sejarah Perkembangan). Bandung: PT. Citra Aditya Bakti, 1987.

Departemen Pendidikan dan Kebudayaan Republik Indonesia. "KBBI Daring." Diakses 15 September 2019. https:/ / kbbi.kemdikbud.go.id/entri/ konstitusi.

Hosen, Nadirsyah. Shari'a $\mathcal{E}$ Constitutional Reform in Indonesia. Singapore: ISEAS, 2007.

Mahmuzar. Sistem Pemerintahan Indonesia: Menurut Uud 1945 Sebelum Dan Sesudah Amandemen. Ujungberung, Bandung: Nusa Media, 2010.

Manan, Bagir. Membedah UUD 1945. Malang, Indonesia: Universitas Brawijaya Press, 2012.

Mansur, Bahauddin Mahmud Muhammad. "Fiqh al-Khilafah al-Rasyidah wa al-Tahawwul al-Dimuqrathiy fi Mashr." Al-Azhar, H 1433.

Noviawati, Evi. "Landasan Konstitusional Pembentukan Peraturan Perundang-Undangan." Jurnal Ilmiah Galuh Justisi 6, no. 1 (19 Mei 2018): 53-63. https://doi.org/10.25157/jigj.v6i1.1246.

Sallam, Abu 'Ubayd al-Qasim Ibnu. Kitab al-Amwal. Kairo: Dar al-Fikr, 1975. Soetoprawiro, Koerniatmanto. “Konstitusi: Pengertian Dan Perkembangannya." Jurnal Pro justitia, no. 2 (1987).

Strong, C. F. Konstitusi-Konstitusi Politik Modern: Studi Perbandingan Tentang Sejarah Dan Bentuk. Bandung: Penerbit Nusa Media, 2014.

Sukardja, Ahmad, dan Ahmad Sukardja. Piagam Madinah E Undang-Undang Dasar 1945 Nri 1945: Kajian Perbandingan Tentang Dasar Hidup Bersama Dalam Masyarakat Yang Majemuk. Rawamangun, Jakarta: Sinar Grafika, 2012. 
Ṭabarī, Nawāf. Tārìkh Al-Ṭabarī: Tārìkh Al-Umam Wa-Al-Mulūk. Al-Ṭab‘ah 1. Bayrūt: Dār Șādir, 1987.

Taj, Abdurahman. "al-Siyasah al-Syar'iyyah wa al-Fiqh al-Islamiy." AlAzhar, H 1434.

Thaib, H. Dahlan. Teori Dan Hukum Konstitusi. Jakarta: PT RajaGrafindo Pesada, 2005.

Wheare, K. C. Konstitusi-Konstitusi Modern. Diterjemahkan oleh Muahmmad Hardani. Surabaya: Pustaka Eureka, 2003.

Yusdani, Yusdani. "Indonesia, Islam and Multicultural Citizenship." Millah: Jurnal Studi Agama 18, no. 1 (31 Desember 2018): 1-14. https://doi. org/10.20885/millah.vol18.iss1.art1. 